\title{
SFORMALIZOWANA ANALOGIA PROPORCJONALNOŚCI W UJĘCIU JÓZEFA MARII BOCHEŃSKIEGO I JEJ ZASTOSOWANIE W DYSKURSIE RELIGIJNYM
}

\begin{abstract}
JÓZEF MARIA BOCHEŃSKI'S FORMALIZED ANALOGY OF PROPORTIONALITY AND ITS APPLICATION IN RELIGIOUS DISCOURSE

The article presents a formal scheme of the analogy of proportionality formulated by Józef Maria Bocheński. Bocheński applies his theory to religious discourse in order to claim that the meaning of this discourse does not have to be established exclusively in a negative way, in opposition to the claims made by negative theology. The aim of this article is to show that the application of analogy to religious discourse does not work. Bocheński's theory is criticized in three aspects. Firstly, by adopting the assumptions of the theory of analogy, one can easily prove that some relations considered within religious discourse are indistinguishable, thus leading to confusion. Secondly, analogy as utilized by Bocheński takes only the formal properties of relations into account, making religious discourse almost materially empty. Thirdly, any attempt to treat analogy as an isomorphism of relations results in difficulties with defining the domains of these relations. The conclusion emphasizes one more fact: the analogy of proportionality offered by Bocheński and applied to religious discourse is simply impractical and useless since nobody uses it.

Keywords: analogy, religious discourse, isomorphism, negative theology, positive theology
\end{abstract}

Artykuł bada efektywność analogii proporcjonalności zdefiniowanej w sposób formalny przez Józefa Marię Bocheńskiego w kontekście jego dociekań na temat dyskursu religijnego. Zastosowaniem analogii w dyskursie religijnym lub teologicznym zajmowali się również tacy autorzy, jak m.in. Richard Swinburne (1993, 1995), Dorothy Emmet (1961), Ian Barbour (1984) czy Claudio Testi (2004). Można tu wymienić również Gianfranca Bastiego czy Fabia

* Instytut Nauk Teologicznych, Uniwersytet Szczeciński, ul. Papieża Pawła VI 2, 71-459 Szczecin, e-mail: krzysztof.jaworski@usz.edu.pl, ORCID: http://orcid.org/oooo-ooo1-8311$780 X$. 
Bertata, którzy prowadzili badania z zakresu ontologii formalnej lub formalnej teologii naturalnej.

Według Bocheńskiego (1990: 89-90) analogia, jako metoda na zrozumienie wypowiedzi odnoszących się do Boga, jest podwójnym antidotum: z jednej strony na pesymizm teologii negatywnej, z drugiej - na zbytni optymizm teologii pozytywnej.

Teologia negatywna (zwana też teologią apofatyczną) to nurt, w którym przyjmuje się, że znaczenie zdań dyskursu religijnego może być określone jedynie na drodze negacji (Rojek 2010: 192-215). Przedstawiciele teologii negatywnej twierdzą, że między Bogiem a człowiekiem rozpościera się „ontyczna otchłań”, w związku z czym Bóg w żaden sposób nie jest „podobny” do tego, jak my ludzie o nim myślimy czy mówimy. Oznacza to, że każda wypowiedź o Bogu przypisująca Mu jakieś własności pozytywne musi być nietrafna z racji ograniczeń naszego poznania. Nie możemy o Nim powiedzieć nawet, że jest dobry, ponieważ dysponujemy tylko ludzkim pojęciem dobroci („dobry człowiek”, „dobra kawa”, „dobry mecz”, „dobra rada”), a takie pojęcie nigdy nie oddaje w sposób wyczerpujący treści pojęcia dobroci należącej do natury Boga. Innymi słowy, ludzkie pojęcie dobroci odniesione do Boga zawsze zawęża pojęcie dobroci Bożej. Z kolei mówiąc „Bóg nie jest dobry” wyznawca teologii negatywnej nie stwierdza, że Bóg jest zły, lecz że Bóg nie jest dobry taką dobrocią, jakiej pojęciem człowiek dysponuje. Bocheński, wbrew zarzutom niektórych uczonych (Pouivet 2013: 44-45), nie znajduje sprzeczności w założeniach teologii negatywnej. Uważa natomiast, że teologia negatywna jest nie do pogodzenia $\mathrm{z}$ dyskursem religijnym jako całością i że trudno oddawać cześć komuś, komu nie można przypisać żadnej własności pozytywnej. Stąd teologię negatywną należy odrzucić (Bocheński 1990: 87).

Na drugim biegunie znajduje się teologia pozytywna (zwana także teologią katafatyczną), w myśl której nic nie stoi na przeszkodzie, by język „ludzki” mógł dokonać rzetelnego opisu Boga. Wiedząc na przykład, kim jest mądry człowiek, możemy z powodzeniem stwierdzić, że mądry jest i Bóg. Teologia katafatyczna jednak - jak zauważa Bocheński - musi zmierzyć się z trudnym problemem tajemnicy. Okazuje się bowiem, że pewne stwierdzenia dyskursu religijnego są dla ludzi wierzących niezrozumiałe, a przyjmują je oni jedynie „na wiarę”. Poważny niepokój budzą już nie tylko spektakularnie antynomiogenne pojęcia wszechmocy lub wszechwiedzy Boga, lecz nawet takie proste stwierdzenia jak to, że Bóg jest dobry albo że kocha każdego człowieka.

Bocheński próbuje znaleźć kompromis między teologią negatywną a pozytywną, to znaczy kompromis między stwierdzeniem, że znaczenie terminów należących do dyskursu religijnego może być określone jedynie na zasadzie negacji, a stanowiskiem, zgodnie z którym język religijny wiernie, w sposób 
pełny opisuje naturę Absolutu. Tym kompromisem ma być jego teoria analogii, która z jednej strony „osłabia” znaczenie terminów dyskursu religijnego, a z drugiej nie ogranicza ich tylko do negacji ${ }^{1}$.

Wypada w tym miejscu podać kryteria zastosowania, czy też dziedzinę, w której mogłaby być użyteczna teoria analogii Bocheńskiego. Sam autor uprawianą przez siebie logikę traktuje jako tzw. logikę stosowaną, czyli logikę zaprzęgniętą do konkretnej pozalogicznej dziedziny. W tym wypadku ową pozalogiczną dziedziną jest religia (czy religie), której treść wyraża szczególny język, zwany dyskursem religijnym (Bocheński 1990: 11-17). Dyskurs religijny jest czymś zastanym, faktem empirycznym - podobnie jak faktem są same religie. Religie są konkretnym zjawiskiem społecznym i to one właśnie są polem zastosowania teorii Bocheńskiego. Co prawda stosowalność logiki na gruncie religii była $\mathrm{w}$ historii niejednokrotnie kwestionowana, ale Bocheński oddala tę krytykę, stwierdzając, że skoro uprawia się takie dyscypliny naukowe jak psychologia religii, socjologia religii itp., to uprawnione jest również mówienie o logice religii, z zastrzeżeniem, że oczywiście logika religii nie jest tym samym co religia (Bocheński 1990: 25). Teoria analogii Bocheńskiego ma zatem „pracować” na konkretnym dyskursie religijnym, a nie na jakimkolwiek teoretycznym namyśle teologicznym² ${ }^{2}$.

\section{ANALOGIA A DYSKURS RELIGIJNY}

W doświadczeniu religijnym (bez względu na rodzaj religii) człowiek nierzadko staje wobec spraw tajemniczych. Według Bocheńskiego zdanie należące do dyskursu religijnego jest tajemnicze dla pewnej osoby między innymi wtedy, gdy zawiera przynajmniej jeden termin zastosowany w sposób tylko częściowo pokrywający się z zastosowaniem w dyskursie świeckim. Ten rodzaj

\footnotetext{
${ }^{1}$ Bocheński przywołuje jeszcze jedną teorię znaczenia - tzw. „teorię tego, co niewysłowione”. Jest to teoria najbardziej skrajna, ponieważ zgodnie z jej założeniami terminy dyskursu religijnego nie posiadają żadnego znaczenia. Teoria tego, co niewysłowione, różni się istotnie od teologii negatywnej. Pierwsza z nich głosi, że dyskurs religijny zupełnie nic nie znaczy, druga natomiast stwierdza, że dyskurs religijny coś jednak znaczy, ale znaczenie to ma charakter wyłącznie negatywny (Bocheński 1990: 29-33, 85).

${ }^{2}$ Już sama nazwa „dyskurs religijny” wskazuje, że przedmiotem zainteresowania Bocheńskiego jest nie tyle dyskurs teologiczny jako taki, ile dyskurs związany z credo konkretnej religii. Materiałem empirycznym jest tu zatem zbiór tez doktrynalnych danej religii, wypowiedzianych w języku świeckim. Znaczenie terminów języka świeckiego jest znane. Pytanie, które stawia Bocheński, brzmi: na ile rzetelnie terminy świeckie oddają naturę rzeczywistości nadprzyrodzonej?
} 
tajemnicy Bocheński nazywa „tajemnicą osłabionego znaczenia” (Bocheński 1990: 83-84). Analogia różni się od teologii negatywnej przede wszystkim tym, że teolog apofatyczny odwołuje się wyłącznie do negatywnych znaczeń tego, co się rozumie pod danym (świeckim) terminem, natomiast w teorii analogii jakaś część pozytywnego znaczenia terminów zostaje zachowana.

Bocheński odróżniał cztery rodzaje analogii: analogia atrybucji, analogia proporcjonalności właściwej, analogia proporcjonalności przenośnej i analogia nierówności. Twierdzil, że dla logiki, filozofii i teologii istotne są dwa pierwsze rodzaje (Bocheński 1948: 75). Zostaną one pokrótce scharakteryzowane w dalszej części wywodu. Mówiąc najogólniej, teoria Bocheńskiego zakłada, że jeżeli jakiś termin dyskursu świeckiego stosuje się w dyskursie religijnym, to świeckie znaczenie tego terminu jest częściowo tożsame, a częściowo różne od jego znaczenia religijnego. Warto zauważyć, że część wspólna znaczenia tego terminu jest pozytywna w zastosowaniu zarówno świeckim, jak i religijnym.

Pierwszym problemem, jaki musi rozwiązać teoria analogii, jest rozstrzygnięcie, którą „część” znaczenia danego terminu można by uznać za wspólną dyskursowi świeckiemu i religijnemu. Inaczej mówiąc, trzeba odpowiedzieć, co ma być analogiczne w dyskursie religijnym i świeckim: własności absolutne czy relacje? Bocheński pisze:

Na gruncie większości religii tak silnie podkreśla się transcendencję przedmiotu religii, że w sposób całkiem naturalny większość autorów, którzy zajmowali się tym problemem, dochodziła do wniosku, że żadnych absolutnych własności nie da się zasadnie przypisać tak przedmiotom, o jakich mowa na gruncie dyskursu świeckiego, jak i przedmiotowi religii (Bocheński 1990: 88).

W myśl tego stwierdzenia Bocheński skupia się na analizie relacji. W przypadku relacji pojawia się jednak istotny problem: trudno przedmiotowi transcendentnemu przypisać ten sam typ powiązań, który charakteryzuje przedmioty dyskursu świeckiego. Na przykład termin „ojciec” oznacza w dyskursie świeckim zbiór relacji badanych przez różnorakie nauki (fizjologię, psychologię, socjologię) i trudno przyjąć, że w te same relacje mógłby wchodzić także Bóg Ojciec. Wierzy się zwykle, że Bóg jest bezcielesny, a zatem nie istnieją żadne powiązania fizjologiczne Boga z człowiekiem:

trzeba zatem stwierdzić, że żadna z relacji składających się na znaczenie terminu „ojciec” na gruncie dyskursu świeckiego nie może być przypisana temuż terminowi w zwrocie „Bóg jest Ojcem” (Bocheński 1990: 89).

W jaki sposób mogłaby więc zachodzić analogia między relacjami badanymi na przecięciu dyskursu religijnego z dyskursem świeckim? Bocheński wysuwa ciekawą propozycję. Odpowiada, że tym, co analogiczne, nie muszą być same relacje jako takie, ale formalne własności tych relacji, na przykład 
ich zwrotność, symetria, przechodniość itp. (Bocheński 1990: 89). Tego typu własności da się zdefiniować za pomocą standardowych funktorów logicznych. Dzięki temu nie ma potrzeby angażowania żadnych metafizycznych założeń. Oto trzy najważniejsze zalety takiego rozwiązania:

- nie można powiedzieć, że dyskurs religijny jest całkowicie pozbawiony znaczenia,

- można przypisać Bogu krańcową transcendencję,

- można prowadzić bardzo ścisłe rozumowania dotyczące Boga.

\section{FORMALNA TEORIA ANALOGII}

Przedstawię teraz teorię analogii formalnie. Jak powiedziałem, Bocheński uważa, że dla logiki, filozofii i teologii najistotniejsze są dwa z czterech wyżej wymienionych głównych rodzajów analogii: analogia atrybucji i analogia proporcjonalności (właściwej). Klasyfikację tych rodzajów analogii przedstawia Diagram 1.

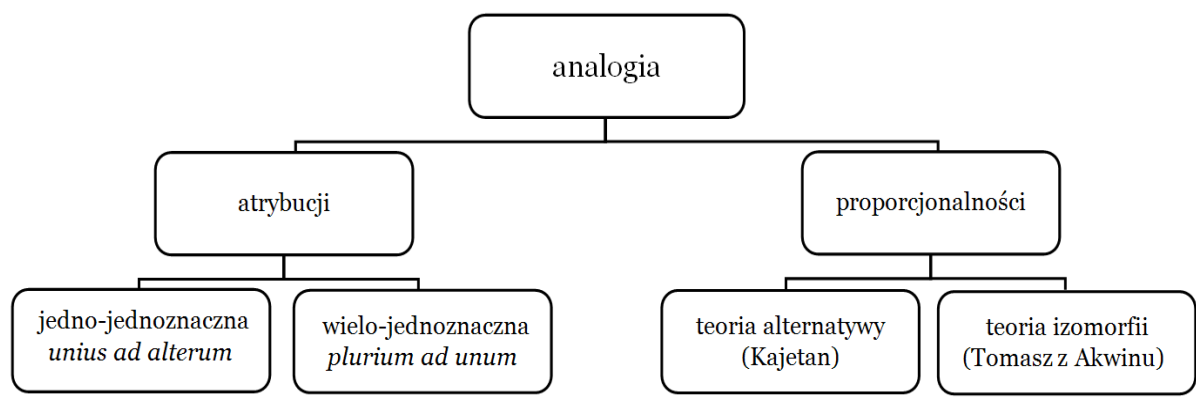

Diagram 1. Rodzaje analogii według Bocheńskiego

Mówiąc najprościej, analogia atrybucji od analogii proporcjonalności różni się tym, że w przypadku pierwszej mamy do czynienia z przyporządkowaniem tego samego terminu do wielu przedmiotów ze względu na relację tych przedmiotów do jakiegoś jednego przedmiotu, zwanego analogatem głównym, do którego treść przypisywanego terminu odnosi się w sposób właściwy; natomiast $\mathrm{w}$ przypadku analogii proporcjonalności mówi się o podobieństwie relacji zachodzącej między pewną własnością i rzeczą posiadającą tę własność do relacji zachodzącej między drugą własnością i rzeczą posiadającą tę drugą własność, przy czym relacje te nie są tożsame (Bocheński 1993: 73). W tym 
wypadku zachodzi nie tożsamość treści, lecz tożsamość relacji (Strzelecki 2013: 29-30). Każdy z tych rodzajów analogii ma jeszcze odmiany, których szczegółowy i formalny opis można znaleźć w pracy Bocheńskiego $O$ analogii (Bocheński 1993: 63-67). Z naszego punktu widzenia istotne jest to, że zdaniem Bocheńskiego $\mathrm{w}$ dyskursie religijnym najlepsze zastosowanie ma analogia proporcjonalności w wersji Tomasza, czyli izomorfia, którą w dalszej części wywodu będziemy nazywać po prostu analogią. Jest to relacja zachodząca między dwoma tzw. kompleksami semantycznymi.

Kompleksem semantycznym nazywamy formułę postaci:

$$
S(a, f, x) \text {. }
$$

Wyrażenie to czytamy: „termin $a$ oznacza własność $f$ w rzeczy $x$ ”. Oryginalnie Bocheński włącza do tej definicji jeszcze dodatkową zmienną, dzięki której staje się możliwe uwzględnienie języka, w którym się mówi. Przyjmijmy dla uproszczenia, że będziemy posługiwać się tylko jednym językiem (polskim), co pozwoli pominąć kwestię języka w dalszej części wywodu. To uproszczenie nie wpływa w żaden sposób na wyniki analiz.

Między dwoma kompleksami semantycznymi może zachodzić pewna sześcioczłonowa relacja $R$, czyli relacja między dwoma terminami, dwoma przedmiotami i dwiema własnościami tych przedmiotów:

$$
R(a, b, f, g, x, y),
$$

gdzie „a" i „b" to nazwy terminów, ,f” i „ $g$ ” to symbole własności, a „, $x "$ i , $y$ ” to nazwy przedmiotów. Relację $R$ można zdefiniować w następujący sposób:

$$
R(a, b, f, g, x, y) \stackrel{\text { def }}{=} S(a, f, x) \wedge S(b, g, y) .
$$

Dla stwierdzenia, że dwa terminy mają tę samą postać, Bocheński rezerwuje predykat $I$. Zatem napis „ $I(a, b)$ ” będziemy czytać: „terminy $a$ i $b$ są tej samej postaci”, a napis „ $\neg I(a, b)$ ”: „terminy $a$ i $b$ mają różną postać”. Posługując się predykatem $I$, zdefiniujmy teraz pojęcie jednoznaczności3.

$$
U n(a, b, f, g, x, y) \stackrel{\text { def }}{=} S(a, f, x) \wedge S(b, g, y) \wedge I(a, b) \wedge f=g \wedge x \neq y .
$$

Jednoznaczność jest relacją między dwoma kompleksami semantycznymi, w których występują dwie równokształtne nazwy $(I(a, b))$, nieidentyczne indywidua $(x \neq y)$ oraz identyczne treści $(f=g)$. Przykładowo jednoznaczność zachodzi między terminami „blondyn” w wyrażeniach:

(a) „Marek jest blondynem”: $S($ „blondyn”, posiadanie jasnych włosów, Marek),

${ }^{3}$ Symbol „Un” pochodzi od lacińskiego „univoca”. 
„Jacek jest blondynem”: $S($ „blondyn”, posiadanie jasnych włosów, Jacek).

Podobnie można zdefiniować pojęcie wieloznaczności

$$
A e(a, b, f, g, x, y) \stackrel{\text { def }}{=} S(a, f, x) \wedge S(b, g, y) \wedge I(a, b) \wedge f \neq g \wedge x \neq y .
$$

Wieloznaczność jest relacją między dwoma kompleksami semantycznymi, w których występują dwie równokształtne nazwy $(I(a, b))$, dwie różne treści $(f \neq g)$ oraz dwa nieidentyczne indywidua $(x \neq y)$. $Z$ wieloznacznością mamy do czynienia w następujących wyrażeniach:

„Twoja żmija jest jadowita”: $S($,jadowita”, dysponowanie trującym jadem, żmija),

$$
\text { „Twoja teściowa jest jadowita”: } S(\text {,jadowita”, bycie przykrą osobą, }
$$
teściowa).

W podanych kompleksach semantycznych występują dwa terminy tej samej postaci: „jadowity”, „jadowity”, dwie różne treści tych terminów: dysponowanie trującym jadem i bycie przykrą osobą, oraz odpowiednio dwie nazwy przedmiotów: żmija i teściowa. Zgodnie z definicją między tymi kompleksami semantycznymi zachodzi wieloznaczność.

Zanim formalnie wprowadzimy definicję analogii, poddajmy ten schemat podstawowy pewnej modyfikacji. Bocheński twierdził, że przedmiotowi religii nie sposób, bez popadania w pułapki teologii negatywnej, przypisywać własności absolutnych. Można natomiast analizować pewne relacje, w jakie wchodzi przedmiot religii (Moskal 1997: 109-110). W związku z tym w schemacie korelatu semantycznego własność absolutną $f$ zastąpimy relacją $Q$, a zamiast nazwy przedmiotu $x$ wprowadzimy parę przedmiotów $[x, y]$ :

$$
S(a, Q,[x, y]) .
$$

Podaną formułę należy czytać: „termin $a$ oznacza relację $Q$, w którą przedmiot $x$ wchodzi z przedmiotem $y$ ". Możemy oczywiście zdefiniować również relację $R$, zachodzącą między dwoma korelatami:

$$
R(a, b, P, Q,[x, y],[z, t]) \text {. }
$$

Schemat ten głosi: „termin $a$, oznaczający relację $P$, w której przedmiot $x$ pozostaje z przedmiotem $y$, jest w relacji $R$ z terminem $b$, oznaczającym relację $Q$, w której przedmiot $z$ pozostaje z przedmiotem $t$ ". Możemy przykładowo powiedzieć: „Jacek jest ojcem Jakuba” oraz „Arystoteles jest ojcem logiki”. Między Jackiem a Jakubem zachodzi relacja ojcostwa oraz między Arystotele-

4 Symbol „Ae” pochodzi od łacińskiego „aequivoca”. 
sem a logiką zachodzi relacja ojcostwa. Wiemy jednak, że charakter tych dwóch relacji ojcostwa (mimo równoksztaltności obu terminów oznaczających ojcostwo) jest zasadniczo odmienny. Zgodnie z tymi ustaleniami, definicja analogii (proporcjonalności) przyjmie postać:

$$
\begin{aligned}
\operatorname{Anb}(a, b, R, Q,[x, y],[z, t]) & \stackrel{\text { def }}{=} S(a, R,[x, y]) \wedge S(b, Q,[z, t]) \wedge \\
& \wedge I(a, b) \wedge R \neq Q \wedge[\mathrm{x}, y) \neq[z, t] \wedge i z(R, Q) .
\end{aligned}
$$

Napis „iz $(R, Q)$ ” czytamy: „relacja $R$ jest izomorficzna z relacją $Q$ ”. Tę definicję można skrócić, ponieważ pierwsza część jej definiensa jest po prostu charakterystyką wieloznaczności:

$$
A n p(a, b, R, Q,[x, y],[z, t]) \stackrel{\text { def }}{=} A e(a, b, R, Q,[x, y],[z, t]) \wedge i z(R, Q) .
$$

W definicji tej Bocheński stosuje pojęcie izomorfizmu „iz”. Trzeba poświęcić temu chwilę uwagi, ponieważ określenie izomorfizmu zgodne z założeniami filozoficznymi Bocheńskiego odegra istotną rolę w dalszej części tej pracy.

W jednym ze swoich pierwszych artykułów na temat analogii, zatytułowanym Wstęp do teorii analogii, Bocheński pisze:

Użyjemy metod współczesnej logiki matematycznej i semantyki: zakładamy u Czytelnika znajomość symboliki peano-russellowej, polskiej terminologii logicznej i semantycznej, a także elementarnych metod używanych w Principia Mathematica (Bocheński 1948: 64).

Sięgając z kolei do drugiego tomu dzieła Whiteheada i Russella (1927: 295), dowiadujemy się, że relacja $P$ jest „podobna zwyczajnie” (similar ordinarly) do relacji $Q$ (co zapisuje się „P smor $Q$ ”) wtedy i tylko wtedy, gdy istnieje wzajemnie jednoznaczna relacja $S$ (będąca korelatorem) odwzorowująca dziedzinę relacji $P$ na dziedzinę relacji $Q$ tak, że:

$$
\text { jeżeli } x P y \text {, to (jeżeli } x S w \text { i } w Q z \text {, to } z \breve{S} y \text { ). }
$$

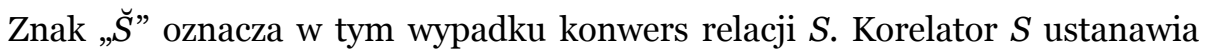
właśnie izomorfizm między relacjami $P$ i $Q$ (Linsky, Andrew 2021). Możemy przyjąć, że Bocheński posługiwał się pojęciem izomorfizmu w takim znaczeniu. Stosował on nawet taką samą notację, jaka występuje w Principia Mathematica („P smor Q”). Taką też definicję izomorfizmu znajdujemy w tekście Bocheńskiego Gedanken zur mathematisch-logischen Analyse der Analogie z roku 1956 (Moskal 1996: 138, Menne 1959: 393, Bocheński 1990: 120-121).

\footnotetext{
$5 \mathrm{~W}$ pismach Bocheńskiego długo trzeba szukać formalnej definicji izomorfizmu. Filozof formułuje, co prawda, „teorię izomorfii”, ale termin ten oznacza po prostu sformalizowaną teorię analogii proporcjonalności, która to teoria posługuje się zastanym pojęciem izomorfizmu (Bocheński 1993: 72-75). Innymi słowy, celem teorii izomorfii jest podanie formalnej definicji analogii proporcjonalności, korzystającej z pojęcia izomorficzności relacji.
} 
Spróbujmy zapisać definicję izomorfizmu relacji bardziej formalnie, w języku współczesnej logiki, ale zgodnie z zamysłem Bocheńskiego.

DEFINICJA 1 (FUnKCJA USTALAJĄCA IZOMORFIZM RELACJI) Funkcja $f$ ustala izomorfizm relacji $R$ z relacją $S$ wtedy i tylko wtedy, gdy $f$ ustala równoliczność pól relacji $R$ i $S$ oraz dla każdego $x, y: x R y$ wtedy i tylko wtedy, gdy $f(x) S f(y)$ :

$$
R i z_{f} S \equiv \mathrm{C}(\mathrm{R}) \sim f C(S) \wedge \forall x, y:(x R y \equiv f(x) S f(y)) .
$$

DEFINICJA 2 (IZOMORFIZM RELACJI) Dwie relacje są izomorficzne wtedy i tylko wtedy, gdy istnieje funkcja wzajemnie jednoznaczna $f$, która odwzorowuje pole pierwszej relacji na pole drugiej relacji w taki sposób, że pierwsza relacja zachodzi między dowolnymi przedmiotami wtedy i tylko wtedy, gdy druga relacja zachodzi między ich obrazami wyznaczonymi przez funkcję $f$ :

$$
R i z S \equiv \exists f: R i z_{f} S .
$$

Można pośrednio stwierdzić, że analogia proporcjonalności zachodzi między dwoma wieloznacznymi terminami $a$ i $b$, odnoszacymi się odpowiednio do dwóch różnych relacji $R$ i $Q$, które to relacje sa izomorficzne. Ponieważ zaś relacje $R$ i $Q$ są izomorficzne, własności formalne obu tych relacji są takie same (Kuratowski, Mostowski 1978: 96-97).

Rozważmy dla przykładu dwa zdania:

$$
\text { „Marcin jest ojcem Andrzeja”, }
$$

$$
\text { „Bóg jest ojcem Piotra”. }
$$

Znamy znaczenie słowa „ojciec” w dyskursie świeckim (przyjmijmy, że chodzi o ojcostwo biologiczne). Zastanówmy się teraz, co mogłoby znaczyć to słowo $\mathrm{w}$ dyskursie religijnym. Zdefiniujmy dwa kompleksy semantyczne, charakteryzujące powyższe zdania:

$$
\text { S(„ojciec”, ojcostwo biologiczne, [Marcin, Andrzej]), }
$$

$$
S \text { („ojciec”, ojcostwo nadprzyrodzone, [Bóg, Piotr]). }
$$

W przykładzie występują dwa terminy tej samej postaci: „ojciec” i „ojciec”, dwie relacje: ojcostwo biologiczne i ojcostwo nadprzyrodzone, oraz dwie pary przedmiotów spełniających te relacje: Marcin i Andrzej oraz Bóg i Piotr. Zgodnie z właściwą definicją między kompleksami semantycznymi (1) i (2) zachodzi analogia, to znaczy treść relacji ojcostwa w dyskursie świeckim nie jest identyczna $\mathrm{z}$ treścią relacji ojcostwa $\mathrm{w}$ dyskursie religijnym, ale własności wspólne obu tym relacjom ojcostwa, czyli ich własności formalne, dające się scharakteryzować za pomocą terminów czysto logicznych, oznaczane przez analogiczne słowa, są identyczne: wszystkie formalne własności jednej relacji 
są formalnymi własnościami drugiej i na odwrót. Na przykład, relacja ojcostwa biologicznego jest przeciwzwrotna, asymetryczna i nieprzechodnia i taka też musi być relacja ojcostwa łącząca Boga z człowiekiem.

Trzeba w tym miejscu zauważyć, że takie postawienie problemu co prawda niewiele mówi na temat samej treści pojęć stosowanych w dyskursie religijnym, ale pozwala na uniknięcie problemów dotykających teologię negatywną - dzięki analogii jesteśmy w stanie powiedzieć o Bogu coś pozytywnego.

\section{EFEKTYWNOŚĆ TEORII ANALOGII}

Teoria analogii zastosowana do dyskursu religijnego jest podatna na przynajmniej trzy zarzuty. Po pierwsze, przeniesienie na dyskurs religijny jedynie własności formalnych relacji zachodzących $\mathrm{w}$ świecie przyrodzonym może skutkować nieoczekiwanym utożsamieniem niektórych relacji w dyskursie religijnym, co raczej nie jest efektem pożądanym. Po drugie, ograniczenie dyskursu religijnego wyłącznie do analizy własności formalnych relacji czyni orzekanie o sprawach Bożych zdecydowanie zbyt ubogim. Po trzecie, problematyczny jest sam izomorfizm - trudno po stronie dyskursu świeckiego określić dziedzinę relacji, która miałaby być izomorficzna z relacją występującą w dyskursie religijnym. Omówię teraz pokrótce te trzy zarzuty.

\subsection{PROBLEM ROZPOZNAWALNOŚCI RELACJI}

Rozważmy następujące stwierdzenia należące odpowiednio do dyskursu świeckiego i religijnego (a konkretnie dyskursu katolickiego):

$$
\text { „Marek jest ojcem Piotra”, }
$$

$$
\text { „Bóg jest ojcem Syna”. }
$$

W wyrażeniu (2), mówiąc „Bóg”, mamy na myśli Boga Ojca, pierwszą osobę Trójcy Świętej, natomiast mówiąc „Syn” - drugą osobę Trójcy. Według teologii katolickiej istnieje jeden Bóg w trzech osobach, między którymi zachodzą określone relacje ${ }^{6}$. Każda z przykładowych wypowiedzi - zarówno wypowiedź (1),

\footnotetext{
${ }^{6}$ Por. Katechizm Kościoła Katolickiego 1994: 69 (§ 255): „Rzeczywiste rozróżnienie Osób Boskich - ponieważ nie dzieli jedności Bożej - polega jedynie na relacjach, w jakich pozostaje jedna z nich w stosunku do innych: »W relacyjnych imionach Osób Boskich Ojciec jest odniesiony do Syna, Syn do Ojca, Duch Święty do Ojca i Syna; gdy mówimy o tych trzech Osobach, rozważając relacje, wierzymy jednak w jedną naturę, czyli substancję«. Rzeczywiście, »wszystko jest (w nich) jednym, gdzie nie zachodzi przeciwstawność relacji«”.
} 
jak i (2) - mówi o relacji ojcostwa. Liczne świadectwa biblijne oraz doświadczenie potoczne przekonują nas jednak, że relacja Ojca do Syna jest zgoła innym ojcostwem niż relacja zachodząca między dwojgiem ludzi. Potrafimy w stosunkowo precyzyjny sposób zdefiniować ojcostwo „ziemskie”, na przykład: $x$ jest ojcem $y$ wtw, gdy $x$ jest przodkiem $y$ w I stopniu linii prostej i $x$ nie jest matką $y$. Znamy konkretne własności materialne relacji ojcostwa „ziemskiego”, tymczasem ojcostwa pierwszej osoby Trójcy Świętej nie da się zdefiniować w taki sam sposób, za pomocą terminów świeckich. Według Bocheńskiego analogia proporcjonalności pozwala przenieść rozumienie określonych relacji z dyskursu świeckiego na dyskurs religijny:

Teologia [...] operuje [...] olbrzymią i skomplikowaną siecią relacji zachodzących między przedmiotami nadprzyrodzonymi. O tych przedmiotach niczego wprost nie wiemy quid Deus sit, nescimus - ale na podstawie objawienia przenosimy w świat nadprzyrodzony cechy formalne stosunków znanych nam doświadczalnie (Bocheński 1949: 180).

Zgodnie z postulatem Bocheńskiego, wolno nam zatem przenieść do dyskursu religijnego jedynie własności formalne relacji ,ziemskich”. Kłopot w tym, że przecież ten sam zbiór własności formalnych może przysługiwać kilku materialnie różnym relacjom. Jeżeli zatem jedynym sposobem mówienia o przedmiotach świata nadprzyrodzonego byłaby analiza własności formalnych relacji, w które te przedmioty wchodzą, to niektóre relacje na gruncie dyskursu religijnego okazałyby się nieodróżnialne (te relacje, które posiadają identyczne własności formalne). Sens tego rozumowania pokazuje prosty przykład. Weźmy dwie relacje świata przyrodzonego: ojcostwo i synostwo. Każda z nich jest asymetryczna, przeciwzwrotna i nieprzechodnia. Jest rzeczą oczywistą, że na gruncie dyskursu świeckiego ojcostwo i synostwo są dwiema zupełnie różnymi relacjami. Jeśli jednak weźmiemy w nawias treść tych relacji, czyli ich własności materialne, a poddamy analizie jedynie ich (identyczne) własności formalne, by następnie te własności formalne przenieść na grunt dyskursu religijnego, to w dyskursie religijnym bycie Ojcem będzie nie do odróżnienia od bycia Synem (właśnie ze względu na identyczność własności formalnych ojcostwa i synostwa). Oczywiście ten przykład obrazuje wspomniany problem w sposób bardzo uproszczony. Możemy chyba jednak wypowiedzieć wniosek ogólny, zgodnie z którym:

- albo istnieją takie relacje, które posiadają te same (i tylko te) własności formalne - wówczas relacje te są od strony formalnej rzeczywiście nieodróżnialne (jak w powyższym przykładzie),

- albo każda relacja posiada unikalny zestaw własności formalnych i wówczas od strony formalnej jest ona rozpoznawalna właśnie po tych własnościach. 
Wydaje się, że Bocheński opowiada się za drugą z tych możliwości, przyznając jednocześnie, że obecny (ówczesny) stan rozwoju nauk formalnych nie pozwala na definiowanie wszystkich własności formalnych danych relacji. Przeciwnego zdania jest Józef Herbut (1963: 29-30), który rozważa, czy dla stosunków transcendentalnych da się wyróżnić jakieś własności strukturalne jednoznacznie je charakteryzujące:

Jeżeli więc dla relacji transcendentalnych każdego typu z osobna nie da się ustalić zespołu charakterystycznych własności formalnych, to tym samym nie widać podstawy do tego, by podobieństwo między nimi sprowadzić do odpowiedniości formalnej (Herbut 1963: 30).

Herbut konkluduje:

Być może, że za koncepcją Bocheńskiego kryje się pogląd, iż współczesna logika formalna pozostaje w bliskim związku z klasyczną ontologią, albo nawet stanowi jej pewną część i że prawa logiczne są prawami bytu w ogólności. [...] wydaje się, że przyjąwszy tego rodzaju pogląd, zatraca się specyficzny treściowy charakter poznania metafizykalnego i metafizykalne wyrażenia o znaczeniu analogicznym sprowadza się do wyrażeń jednoznacznych (Herbut 1963: 37).

Sama idea stosowania izomorfizmu w celu identyfikacji relacji albo orzekania o nich jest szczególnie wątpliwa dla przedstawicieli nauk formalnych. Obiektów izomorficznych nie da się bowiem odróżnić tylko na podstawie własności użytych do zdefiniowania izomorfizmu, ponieważ wówczas musiałyby one być uznane zawsze za identyczne. $\mathrm{Z}$ tym wiąże się kolejny problem teorii Bocheńskiego, omówiony niżej.

\subsection{PROBLEM UBÓSTWA TREŚCIOWEGO}

Problematyczna jest także sama operacja przeniesienia własności formalnych relacji. Żeby lepiej to zobrazować, posłużymy się przykładem zaczerpniętym z matematyki. Zgodnie z tzw. graficzną koncepcją zbioru, mając dany zbiór $A$ i relację $\in$ bycia elementem, możemy zawsze zdefiniować graf $G$, będący obrazem zbioru $A$, i relację $\longleftrightarrow$ bycia dzieckiem węzła w grafie $G$. Innymi słowy, jeżeli $B \in A$ w teorii mnogości, to w teorii grafów możemy zdefiniować graf, w którym od węzła $p$ biegnie krawędź skierowana do węzła $q$. Mówimy wówczas, że graf $G$ jest obrazem zbioru $A$, a dokładnie: węzły $p$ i $q$ są obrazami odpowiednio zbiorów $A$ i $B$. Mamy więc do czynienia z dwoma różnymi teoriami - teorią zbiorów i teorią grafów - a każda $\mathrm{z}$ tych teorii rozważa obiekty i relacje, które nie występują w drugiej (Jaworski 2017: 197-198). Wiadomo jednak, że relacja $\in$ jest izomorficzna z relacją $\longleftrightarrow$, to znaczy zawsze ilekroć zdefiniujemy zbiór $B$ taki, że $B \in A$, możemy zdefiniować graf, w którym węzeł $q$ jest dzieckiem węzła $p$, czyli $p \mapsto q$. Mówiąc językiem Bocheńskiego, 
relacja $\in$ może być przeniesiona czy „przetransmitowana” z teorii zbiorów do teorii grafów, gdzie jakoś „przeobrazi się” w zupełnie inną relację $\longleftrightarrow$.

Wyobraźmy sobie teraz człowieka, który zna teorię zbiorów z jej strukturą relacyjną $\langle A, \in\rangle$, ale nie ma najmniejszego pojęcia o tym, czym jest graf i relacja $\longleftrightarrow$ (nie wie, że graf składa się z jakichś węzłów i krawędzi). Taki człowiek owszem - mógłby na mocy analogii nabyć jakieś wyobrażenie o strukturze relacyjnej $\langle G, \longleftrightarrow\rangle$, która jest izomorficzna ze strukturą $\langle A, \in\rangle$. Samo to wyobrażenie nie dostarczyłoby mu jednak wiedzy o tym, czym graf jest (że składa się on z węzłów i krawędzi) i - tym bardziej - jaką treść posiada relacja $\longleftrightarrow$. Chodzi o to, że dwa identyczne strukturalnie przedmioty wcale nie muszą być do siebie podobne. $Z$ drugiej strony, dwa podobne przedmioty nie muszą posiadać tej samej struktury (Buda 2006: 133). Mówiąc krótko, „należeć do zbioru” znaczy co innego niż „być dzieckiem węzła w grafie”, bez względu na to, że relacja należenia ma strukturę izomorficzną z relacją bycia dzieckiem węzła. Takich przykładów można podać dużo więcej, np. relacje większości i mniejszości w zbiorze liczb rzeczywistych są izomorficzne, ponieważ ich izomorfizm ustala relacja zachodząca między $x$ i $y$ wtedy i tylko wtedy, gdy $y=-x$, a jednocześnie „być większym” znaczy zgoła co innego niż „być mniejszym”. Własności formalne mówią nam coś o relacjach, ale jest to bardzo niewiele, natomiast nie mówią nic ani na temat treści relacji, ani na temat członów relacji. W wypadku dyskursu religijnego izomorfizm ojcostwa człowieka z ojcostwem Boga nie dostarcza nam żadnej materialnej wiedzy ani o tym, kim jest Bóg Ojciec, ani o tym, kim jest Syn Boży, choć dostarcza nam jakiejś częściowej wiedzy na temat relacji ojcostwa. Mimo to sama treść Bożego ojcostwa nadal pozostaje nieznana.

Bocheński zdawał sobie sprawę z zarzutów, które zostaną skierowane przeciwko niemu:

Ktoś może sobie zapewne pomyśleć, że gdyby tak przedstawiała się analogia proporcjonalności, znaczenie naszych zdań o duszy, Bogu itd. byłoby niesłychanie ubogie, a w istocie ograniczałoby się do pewnych bardzo nielicznych relacji formalnych, wyliczonych w Principia Mathematica. Tak jednak nie jest. To prawda, że nie potrafimy, jak dotąd, sformułować ściśle wielu własności formalnych występujących w relacjach, którymi posługują się metafizyka i teologia. Powodem tego nie jest wszakże brak takich własności formalnych, ale bardzo niski poziom rozwoju biologii i innych nauk, z których metafizyk i teolog muszą czerpać swoje analogiczne nazwy (i treści). Formalizacja tych dyscyplin przyczyniłaby się do ogromnego postępu nauk spekulatywnych (Bocheński 1993: 73-74).

Do wspomnianego zarzutu Bocheński nawiązuje także we wcześniejszej pracy, usprawiedliwiając poglądy Jana Drewnowskiego: 
Odpowiedziałby on [Drewnowski] zapewne, że ma na myśli nie tylko cechy stosunków opracowywanych w dotychczasowej logice, ale całą masę innych cech, występujących w zakresie innych nauk, a dotąd nigdy formalnie nie zbadanych. Teologia wychodziłaby nie tylko z logiki, ale głównie z fizyki, biologii, psychologii itd., przenosząc izomorficznie struktury ich przedmiotów w dziedzinę nadprzyrodzoną (Bocheński 1949: 180-181).

Można odnieść wrażenie, że optymizm Bocheńskiego związany z postępem nauki w kontekście rozważanej kwestii jest mocno przesadzony. Wydaje się bardziej niż prawdopodobne, że rozwój nauk i ich formalizacja nigdy nie będą dostatecznie rozwinięte, by stało się możliwe podanie takiej liczby własności formalnych analizowanych relacji, że będzie można precyzyjnie rzutować te relacje ze świata przyrodzonego na świat nadprzyrodzony. $Z$ tego samego powodu wątpliwe jest, by kiedykolwiek można było podać zestaw takich własności formalnych, które będą charakteryzowały tylko jedną konkretną relację (zawsze znajdą się relacje o identycznych własnościach formalnych, a więc jak pokazaliśmy - relacje w teorii Bocheńskiego nieodróżnialne). Nawet gdyby spełniła się kiedyś przepowiednia autora Logiki religii, to prawdopodobnie jego teoria i tak pozostałaby bezużyteczna - fakty przemawiają za przyjęciem tezy, że ludzie religijni posługują się terminami języka religijnego najczęściej w sposób metaforyczny, odnosząc się do własności materialnych relacji. „Bóg jest Ojcem” znaczy „,jest przyczyną”, ,jest wychowawcą”, „jest opiekunem”, „jest osobą kochającą", ,jest trybunałem sprawiedliwości” itp. Skuteczność teorii analogii na gruncie dyskursu religijnego jest więc chyba skazana na pozostanie tylko pobożnym życzeniem. Teoria Bocheńskiego musi raczej ustąpić miejsca hermeneutyce.

\subsection{ANALOGIA A IZOMORFIZM}

Bocheński pisze, że według Drewnowskiego analogia jest izomorfią, czyli „stosunkiem między dwoma stosunkami, który pozwala o jednym z nich orzekać bardzo wiele cech przysługujących drugiemu, aczkolwiek nie znamy wcale terminów tego stosunku" (Bocheński 1949: 180). Poza zarzutami, które wysunąłem (szczególnie $\mathrm{w}$ punkcie 3.2) przeciwko takiemu ujęciu analogii, można jeszcze zauważyć pewną trudność formalną, związaną z samym zastosowaniem metody analogicznej. Przykładowo, według Bocheńskiego między pewnymi dwoma mężczyznami zachodzi relacja izomorficzna z relacją zachodzącą między dwoma szkolnymi kolegami wtedy i tylko wtedy, gdy jeden z mężczyzn jest ojcem jednego chłopca, a drugi jest ojcem drugiego, przy czym obaj uczniowie są jedynymi synami swych ojców (Moskal 1997: 110, Bocheński 1956: 124). Oznacza to, że Drewnowski, a za nim Bocheński, mówią po prostu o izomorfizmie struktur relacyjnych: $\langle A, R\rangle,\langle B, Q\rangle$, gdzie $A$ jest zbio- 
rem przedmiotów świata przyrodzonego, $B$ jest zbiorem przedmiotów świata nadprzyrodzonego, $R$ jest relacją zachodzącą między przedmiotami należącymi do zbioru $A$, a $Q$ jest relacją zachodzącą między przedmiotami należącymi do zbioru $B$. W części 2 wskazałem, że Bocheński rozumiał izomorfizm klasycznie, jak ma to miejsce w Principia Mathematica. Wolno więc posłużyć się definicją 3 (Borkowski 1991: 165):

DEFINICJA 3 (IZOMORFIZM STRUKTUR RELACYJNYCH) Struktura relacyjna $\left\langle A, R_{1}\right.$, $\left.\ldots, R_{n}\right\rangle$ jest izomorficzna ze strukturą relacyjną $\left\langle B, S_{1}, \ldots, S_{n}\right\rangle$ wtedy i tylko wtedy, gdy:

$$
\exists f:\left(A \sim \sim_{f} B \wedge \forall(1 \leq i \leq n): R_{i} i z_{f} S_{i}\right) .
$$

Jak wynika z definicji 3, podstawowym warunkiem zachodzenia izomorfizmu dwóch struktur relacyjnych jest równoliczność zbiorów, będących dziedzinami badanych relacji (równoliczność ta jest ustalana przez funkcję $f$ ). Powróćmy do przykładu wspomnianego w punkcie 3.2: ilekroć na gruncie teorii mnogości $B \in A$, tylekroć na gruncie teorii grafów $p \mapsto q$, to znaczy: ilekroć zdefiniujemy zbiór $B$, który jest elementem zbioru $A$, tylekroć możemy zdefiniować graf $G$, w którym od węzła $p$ biegnie krawędź skierowana do węzła $q-$ i tylko wtedy. Oznacza to, że zbiorów jest dokładnie „tyle samo” co grafów 7 - uniwersum zbiorów jest równoliczne z uniwersum grafów, każdemu grafowi odpowiada dokładnie jeden zbiór i na odwrót.

Zapytajmy teraz, co powinniśmy mieć na myśli, mówiąc na przykład o relacji ojcostwa jako takiej. Czy jest to ojcostwo jakiejś konkretnej osoby (na przykład w zbiorze mieszkańców jednego domu), czy też może relacja zachodząca w zbiorze wszystkich aktualnie żyjących ludzi, czy może ojcostwem nazywa się relację zachodzącą w zbiorze wszystkich ludzi żyjących kiedykolwiek? Aby stwierdzić izomorfizm między relacją ojcostwa Bożego i ojcostwa przyrodzonego, dziedziny tych relacji - zgodnie z definicją 3 - musiałyby być równoliczne. Dogmat katolicki głosi, że Bóg Ojciec ma dokładnie jednego Syna, zatem relacją izomorficzną z relacją ojcostwa Bożego może być tylko relacja zachodząca między pewnym ojcem ziemskim a jego jedynym dzieckiem. Ojcostwo Boże nie będzie natomiast izomorficzne z ojcostwem mężczyzny posiadającego już dwoje i więcej dzieci. Jeżeli natomiast przyjmiemy - jak głosi często nauka katolicka - że Bóg jest Ojcem wszystkich ludzi, to relacja Jego ojcostwa nie będzie izomorficzna $\mathrm{z}$ żadną relacją ojcostwa przyrodzonego (musiałby bowiem znaleźć się na ziemi ktoś, kto posiada tyle dzieci, ilu ludzi

\footnotetext{
7 Przy założeniu, że do naszej teorii grafów należą wyłącznie tzw. grafy skierowane (accessible pointed graphs), a teoria mnogości jest jakąś wersją teorii hiperzbiorów (zbiorów nieufundowanych).
} 
aktualnie żyje). Najpoprawniej można wybrnąć z tej sytuacji, wprowadzając ograniczenie: ojcostwo Boga względem Syna jest izomorficzne z relacją ojcostwa mężczyzny posiadającego dokładnie jedno (bezdzietne!) dziecko. Jednak czy koszt ratowania teorii izomorfizmu przez ingerowanie w dziedziny relacji nie jest zbyt duży? Czy wiedza o relacji nadprzyrodzonej potrzebna do zastosowania techniki analogii nie jest większa niż wiedza, którą zdobywamy dzięki tej operacji? Tę wątpliwość podziela chyba Stanisław Buda, pisząc:

\begin{abstract}
Aby stwierdzić izomorficzność dwóch relacji, trzeba wskazać dwa identycznie uporządkowane przez nie zbiory, czyli zdefiniować dwa systemy relacyjne. Tego zaś nie można zrobić bez określania ich funkcji, tj. wskazania tego, czego konstrukcję stanowią. Wraz z $F$ [zbiorem własności formalnych] są więc zawsze współmniemane pewne własności materialne relacji, w ten sposób, że oba rodzaje własności są in concreto nie do rozdzielenia. Nie można więc mówić o jakiejś zasadniczej pierwotności jednego względem drugiego (Buda 2006: 134).
\end{abstract}

\title{
PODSUMOWANIE
}

W pracy zbadałem użyteczność formalnej wersji analogii proporcjonalności w dyskursie religijnym. Teorię tę sformułował Józef Maria Bocheński. Choć jest to teoria ciekawa i posiada solidne podstawy filozoficzne, wysunąłem przeciwko niej trzy zarzuty. Po pierwsze, analogia w takim ujęciu prowadzi do nieodróżnialności pewnych relacji, które materialnie są różne. Po drugie, izomorfizm relacji $\mathrm{w}$ dyskursie świeckim $\mathrm{z}$ relacją $\mathrm{w}$ dyskursie religijnym mówi o tych relacjach bardzo niewiele (i nie mówi niczego o przedmiocie dyskursu religijnego). Po trzecie, stwierdzenie izomorfizmu relacji, będącego istotnym warunkiem zachodzenia analogii, wymaga jakiejś uprzedniej znajomości własności materialnych przedmiotów wchodzących w te relacje, a to wbrew intencjom Bocheńskiego - wiedzie ku teologii katafatycznej.

\section{BIBLIOGRAFIA}

Barbour I. (1984), Mity, modele, paradygmaty, Kraków: Znak.

Bocheński J. M. (1948), Wstęp do teorii analogii, „Roczniki Filozoficzne” 1, 64-82.

Bocheński I. (1949), O metodzie teologii w świetle logiki wspótczesnej, „Collectanea Theologica" 21(2-3), 171-192.

Bocheński J. M. (1956), Gedanken zur mathematisch-logischen Analyse der Analogie, „Studium Generale” 9, 121-125.

Bocheński J. M. (1990), Logika religii, tłum. S. Magala, Warszawa: PAX. 
Bocheński J. M. (1993), O analogii [w:] Logika i filozofia. Wybór pism, Warszawa: Wydawnictwo Naukowe PWN, 50-78.

Borkowski L. (1991), Wprowadzenie do logiki i teorii mnogości, Lublin: TN KUL.

Buda S. (2006), Dynamika analogii, „Zagadnienia Filozoficzne w Nauce” 38, 127-141.

Emmet D. (1961), The Nature of Metaphysical Thinking, London: Macmillan.

Herbut J. (1963), O formalnym ujęciu analogii transcendentalnej, „Roczniki Filozoficzne” $11,25-40$.

Jaworski K. (2017), Antynomia kłamcy a teoria hiperzbiorów, „Studia Paradyskie” 27, 187-206.

Katechizm Kościoła Katolickiego (1994), Poznań: Pallottinum.

Kuratowski K., Mostowski A. (1978), Teoria mnogości, Warszawa: Państwowe Wydawnictwo Naukowe.

Linsky B., Andrew D. I. (2021), Principia Mathematica [w:] The Stanford Encyclopedia of Philosophy (Fall 2021 Edition), https://stanford.io/3mUBVfG.

Menne A. (1959), Was ist Analogie?, „Philosophisches Jahrbuch” 67, 389-395.

Moskal P. (1996), Problem użyteczności logiki wspótczesnej $w$ uprawianiu metafizyki. Uwagi metafizyka, „Łódzkie Studia Teologiczne” 5, 133-144.

Moskal P. (1997), Ograniczenia Józefa M. Bocheńskiego OP analitycznej eksplanacji religï, „Łódzkie Studia Teologiczne” 6, 99-139.

Pouivet R. (2013), Bocheński on Divine Ineffability, „Studies in East European Thought” 65(1-2), 43-51. https://doi.org/10.1007/s11212-013-9183-9

Rojek P. (2010), Towards a Logic of Negative Theology [w:] Logic in Religious Discourse, A. Schumann (ed.), Frankfurt: Ontos.

Strzelecki J. (2013), Semantyczna czy formalna teoria analogii Józefa M. Bocheńskiego?, „Filo-Sofija” 21(2), 21-38.

Swinburne R. (1993), The Coherence of Theism, Oxford: Oxford University Press. https:// doi.org/10.1093/0198240708.001.0001

Swinburne R. (1995), Revelation: From Metaphor to Analogy, Oxford: Clarendon Press.

Testi C. A. (2004), Analogia, logica formale e paradossi [w:] Analogia e autoreferenza, F. D’Agostini, G. Basti, C. A. Testi (red.), Milano: Marietti, 267-332.

Whitehead A., Russell B. (1927), Principia Mathematica, vol. II, Cambridge: Cambridge University Press. 